There may be other private institutes and research centres in Britain that are reflecting on the possibility of becoming part of a university, with the accompanying measurable benefit of government grants, but the UGC seems not anxious to encourage such unions at present, when funds are so limited. There are several architectural schools, for example, at present attached to local authority art colleges, which would dearly love to become university departments. The Leeds school is particularly keen on the idea, but has not so far had much joy from the UGC. When there is not enough money in the kitty to pay for expansion in existing university departments, it is natural that there is reluctance on the part of the UGC to take on extra establishments. When the choice lies between paying fees that would have come from other sources for existing students, and providing money for additional students, the UGC's policy is understandable.

\section{Canadian Research Flourishes}

ThE National Research Council of Canada has spent five times more on scholarships and research in the universities in the past ten years than in the previous forty years of its existence. According to the council's annual report, the sum spent on Canadian universities has risen even in this past decade from $\$ 10.5$ million in 1962 to more than $\$ 35.5$ million last year. Nearly half of this sum is spent on grants and equipment, and the report estimates that, on the average, each professor received $\$ 6,400$ for equipment last year, a thousand dollars more than two years ago. Expenditure on university research is expected to continue to increase.

In 1966, the council established post-industrial experience research fellowships of $\$ 6,000$, to allow engineers and scientists in industry a year for research in government or university laboratories. The scheme is to run for a trial period of two years, five fellows being elected in each year. This year, to celebrate its own golden jubilee and the centenary of Canadian confederation, the council has decided to set up a new group of scholarships. These will be awarded to graduates for research leading to doctorates in universities other than those from which they obtained their first degrees. It is hoped by this means to foster cultural exchange between the different regions of Canada, in the spirit of the centennial year.

\section{Homeless Doctors}

Since the University of St Andrews became independent of Dundee University in October this year, it has been impossible for St Andrews medical students to do their clinical training. Most have continued to go to Dundee for this purpose.

On December 19, however, the university announced that a link-up had been established between $\mathrm{St}$ Andrews and the University of Manchester. From 1973 onwards, preclinical students at St Andrews will go to do their clinical training in hospitals in Manchester, at the United Manchester Hospitals, and also at Withington Hospital, which is being developed into a full teaching hospital. Students at St Andrews will study for three years in the faculty of science on an extended preclinical course leading to a BSc degree, before going to Manchester.
A number of medical schools were approached in the hope of finding accommodation and several were willing to take a few students. The agreement with Manchester, on the other hand, will take the whole output of premedical students. According to Professor A. E. Ritchie at St Andrews, the liaison committee which will operate the scheme will probably be made up of Professor A. C. P. Campbell, Dr F. B. Beswick and Mr A. R. Anscombe representing Manchester, and Professor G. R. Tristram, Professor A. E. Ritchie and Professor R. Walmsley representing St Andrews.

\section{Training Manpower}

LAST week the Ministry of Labour announced a new scheme for the training of craft apprentices in the development areas. The scheme extends the range of training grants already made under the levy and grants system introduced by the Industrial Training Act of 1964. The new grants are of two distinct types; one will provide capital grants towards the cost of providing places for training off the job, and the other will reward employers who take on additional trainees for on-the-job training.

The capital grants, the ministry explains, are intended to encourage the provision of places for training off the job. The ministry will agree with the training boards a standard capital cost for providing the premises and equipment for the training. The employers who provide the new premises will get a grant worth 60 per cent of the cost of providing the places. If the employer can increase the number of training places without building new premises, the grant will be 60 per cent of the costs incurred. Grants of similar scale will be given in industries where there is as yet no recognized form of training. The per capita grant is intended for industries where training is normally done on, rather than off, the job. Employers who make more places available for trainees will be entitled to grants equal to $£ 100$ for each additional trainee.

So far, the industrial training boards cover industries which employ over 10 million people, a figure which will soon be increased to 15 million when new boards, already announced, come into operation. Next year the ministry estimates that some $£ 120$ million will be distributed to individual firms as training grants. The ministry is keen to make the schemes known to more firms, and has produced a pamphlet-Assistance with Industrial Training in the Development Areas (HMSO) -which explains them.

\section{British Aircraft}

THE British Government is now the dominant force in British aviation. There is nothing new in this, of course, but the point has been hammered home with particular emphasis in recent months. First there was the decision to build London's third airport at Stansted, then the apparent dithering over the Concorde, finally the announcement that British Aircraft Corporation would not be allowed to build the BAC 2-11. All these are important commercial decisions, but only in the last is it easy to see why the Government acted as it did. Although BAC wanted to build the 2-11, and British European Airways wanted to fly it, nobody wanted to pay for it. According to Mr Crosland, the President of the Board of Trade, it would have cost $£ 120$ million 
to develop, against a mere $£ 15$ million for the Trident $3 \mathrm{~b}$, the alternative aircraft. In the circumstances, it was obvious what the outcome would be.

Despite the cancellation, BAC seems to have plenty of work; for one thing, it will be responsible for the British end of the Concorde production. The BAC 1-11, the company hopes, will continue to sell for a good time yet, and there may still be a few orders for the VC 10 and the Lightning. And the news that the Trident $3 \mathrm{~b}$ is to be developed is bound to be an encouragement to Hawker Siddeley, disappointed by the Government's refusal to sell Buccaneers and Nimrods to South Africa. BEA is expected to want about 40 Tridents, and there may be a few orders from elsewhere now the decision to go ahead has been taken. But BEA will only accept the aeroplane on sufferance, and pre. sumably as collateral to a Government agreement to provide the corporation with a financial reconstruction along the same lines as that enjoyed by BOAC. This is because BEA believes that the Trident will be more expensive to fly than the alternatives, one of which is the Boeing 727-200.

The alarming feature of the situation is not that the Government now pays the piper-that is probably inescapable-but that it is calling such a peculiar medley of tunes. While the Board of Trade has been mulling over the 2-11, the Ministry of Technology has been lavishing its formidable enthusiasm on the European airbus, a collaborative project in which France, West Germany and Britain are involved. To judge by the published reactions of some of the airlines, the airbus is no more immediately attractive than the 2-11. What the Government should now be asking itself is whether the 2.11 would have been more attractive clad in the guise of European collaboration. Looking at it another way, would the airbus have seemed so desirable if BAC had proposed to build it alone? And why should two projects which clearly influence each other be the responsibilities of separate ministries? There is a real danger that the worthwhile aim of European collaboration is being used to justify projects which cannot justify themselves. That kind of muddled thinking will serve nobody's purposes but those of the United States aircraft companies.

\section{Fall-out over Britain}

THREe Chinese nuclear explosions have occurred since the last recorded measurements were made in the United Kingdom of fission products in rainwater and airborne dust. In addition, France tested several nuclear devices in the South Pacific between June 1966 and July 1967. But in spite of this the latest Atomic Energy Authority research group report, Radioactive Fallout in Air and Rain: Results to the Middle of 1967 (UKAEA, 7s.), shows that the concentration of long-lived fission products over the United Kingdom has continued to decrease.

Prepared by the Health Physics and Medical Division of the Atomic Energy Research Establishment in Harwell, Berkshire, the report describes methods of sampling and analysis which were used over the period January 1966-July 1967: the data have been tabulated and, where appropriate, have been presented in graphical form. Airborne dust was sampled at one metre above ground by passing appropriate quantities of air through cylindrical filters of esparto grass paper at a number of stations in Britain, Gibraltar, Hong Kong, and Pretoria and Aspendale in Australia. Samples of rainwater were collected in polythene bottles, containing carrier solution to reduce loss by adsorption, at eight stations in Britain and twenty stations elsewhere. Individual activities were determined either by radiochemical methods or by gamma-ray spectrometry.

The mean deposition of $\mathrm{Sr}-90$ in rainwater at Milford Haven for the first half of 1967 was found to be 50 per cent of that for the first half of 1966 . About onetenth of the long-lived fall-out in early 1967 was attributed to the Chinese explosion of December 28, 1966: this increase was sustained for several months because debris had been injected into the stratosphere. No short-lived fission products, such as iodine-131 from the Chinese explosion of June 17, 1967, were detected in Britain although there is evidence of debris from this explosion in the autumn of 1967 . It is interesting to note that plutonium-238 was released over the southern Indian Ocean in April 1964 when an American satellite containing a SNAP-9A power source of $17 \mathrm{KCi}$ of $\mathrm{Pu}-238$ failed to orbit. During the last few months of 1966, cumulative deposition of long-lived fission products was reduced for the first time as radioactive decay exceeded new deposition. In early 1967, however, deposition again slightly exceeded radioactive decay.

\section{Partially-hearing Children}

A suRver of the special arrangements made to help partially-hearing children has been published this week by the Department of Education and Science. In 1966 there were 162 units for such children in Ensland and Wales, of which the survey, conducted by HM inspectors of schools and medical officers, has covered 74.

The units are attached to schools and their purpose is to enable partially-hearing children to join the ordinary classes as soon as they are capable of doing so. Great care must be exercised in selecting children for the units, because severely deaf or otherwise retarded children will hold back the progress of the others. The survey recommended that more careful attention should be paid to the criteria for selecting children for the units. Children should be seen to have the prospect of learning to speak in a natural way more by listening than by lip-reading, and the unit's teacher should be consulted before selection so as to ensure that the child does not present too heavy a load of additional handicaps.

The survey suggested that units functioned better when they were large enough to include more than one class and more than one teacher. Though most of the units inspected are well supplied with audio-visual equipment and other aids, it is surprising that there has so far been little serious development in the use of programmed instruction or film loops.

All teachers of partially-hearing children are suitably qualified as teachers of the deaf. The survey found little to criticize in the standard of instruction within the units and indeed commended the progress made, but it pointed out that teachers who devote all their time to the units are often unaware of, and tend to underestimate, the standards reached by normal children.

The encouraging tone of the survey is marred only by the widespread lack of understanding found to exist in 